
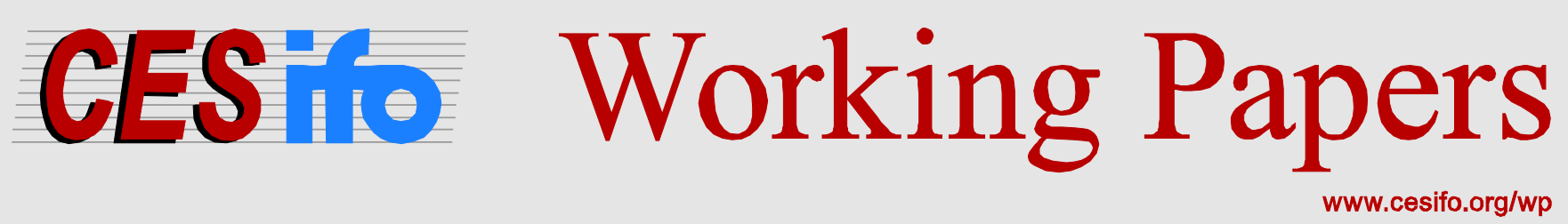

\title{
Ideology and Dissent among Economists: The Joint Economic Forecast of German Economic Research Institutes
}

\author{
Ha Quyen Ngo \\ Niklas Potrafke \\ Marina Riem \\ Christoph Schinke
}

CESIFO WORKING PAPER NO. 5393

CATEgory 2: Public CHOICE

JUNE 2015

An electronic version of the paper may be downloaded

- from the SSRN website:

- from the RePEc website:

WWw.SSRN.com

- from the CESifo website:

www.RePEc.org

www.CESifo-group.org/wp 


\title{
Ideology and Dissent among Economists: The Joint Economic Forecast of German Economic Research Institutes
}

\begin{abstract}
Economists, and also economic research institutes, differ in their attitudes towards desirability of economic policies. The policy positions taken can often be determined by ideology. We examine economic policy positions by investigating minority votes in the Joint Economic Forecast of German economic research institutes. The dataset consists of voting behavior over the period 1950-2014. Our results show that the German Institute for Economic Research (DIW Berlin) submitted by far the most minority votes, consistent with the popular impression that the DIW exhibits a preference for demand-oriented economic policy and has differed from the other leading economic research institutes in this respect. For example, the rate of minority voting of the DIW corresponded to some $300 \%$ of the rate of minority voting of the RWI Essen. Minority votes display an economic research institute's identity. When institutes are known to be associated with specific economic-policy positions, politicians, clients, and voters well understand how to assess the bias in the policy advice that is given.
\end{abstract}

JEL-Code: D720, I230.

Keywords: decision making in committees, minority voting, policy preferences, ideology, Joint Economic Forecast of German economic research institutes.

Ha Quyen Ngo

Ifo Institute, Munich / Germany

Marina Riem

Ifo Institute, Munich / Germany

riem@ifo.de
Niklas Potrafke*

Ifo Institute - Leibniz Institute for

Economic Research

at the University of Munich

Poschingerstrasse 5

Germany-81679 Munich

potrafke@ifo.de

Christoph Schinke

Ifo Institute, Munich / Germany

schinke@ifo.de

*corresponding author

June 9, 2015

21 May 2015 - This paper has been accepted for publication in the Eastern Economic Journal. 


\section{INTRODUCTION}

Economists in general claim to be independent researchers who search for "the truth". The truth is, however, often difficult to establish and there is room for value judgments. Value judgments in economic policies include, for example, the trade-off between equity and efficiency [Hillman 2009, Ch. 7]. Economists' opinions may depend on value judgments associated with schools of thought [Hillman 1998, Prychitko 1998, De Benedictis and Di Maio 2011; 2015, Di Maio 2013]. When economists give policy advice, the advice may therefore be ideologically biased [Coughlin 1989, Frisell 2005, Austin and Wilcox 2007, Kirchgässner 2014]. ${ }^{2}$ Advice is likely to be more effective when economists foreshadow how political ideologies influence the political process [Slembeck 2003]. Ideological positions may be attached to individual economists and have a cumulative effect when economists with similar views work at the same institution. In the United States, it is well-known that thinktanks have ideological positions [McGann 2005]. A question is whether this also holds true for other countries. We investigate whether German economic research institutes differ in economic policy positions and whether the differences in positions influence policy advice.

Leading German economic research institutes that advise the German government have prepared biannual reports on the German and the world economy since 1950. The reports are published in spring and autumn each year. Having independent economic research institutes that write joint reports to give policy advice is unique in industrialized countries. The institutes do not always agree on their assessments of the current situation nor on economic policies that they recommend. An institute that disagrees with a majority position can submit a minority vote. Whether and what kind of minority votes an institute submits is an expression of identity on the ideological spectrum. An institute can express its identity

\footnotetext{
${ }^{2}$ Ideology may influence recommended courses of action. Perceptions of economic-policy norms and political preferences seem to be correlated [Nelson 1987, Alston et al. 1992, Fuchs et al. 1998, Mayer 2001, Klein and Stern 2006, Saint-Paul 2012, Gordon and Dahl 2013]. An area of potential conflict arises when policy advisors try to take into account the beliefs of the client and therefore are cautious with suggestions that may upset the client [Kirchgässner 1996; 1999; 2005; 2011; and 2013].
} 
through economic policy positions in public discourse. Submitting minority votes in the Joint Economic Forecast corroborates particular economic policy positions. The minority votes receive attention. ${ }^{3}$ The media publicize minority votes and the government certainly recognizes that there is disagreement [Fritsche and Heilemann 2010]. Media coverage and economists have assigned ideological labels to the economic research institutes [Langfeldt and Trapp 1988, Döpke 2000, Antholz 2005]. The Kiel Institute for the World Economy (IfW), for example, has been labeled as neoclassical/supply-side, whereas the German Institute for Economic Research in Berlin (DIW) has been labeled Keynesian/demand-side. For institutes given different ideological identities, the question is whether the institutes have disagreed in the Joint Economic Forecast.

We investigate minority votes and how macroeconomic variables influence minority voting. ${ }^{4}$ We distinguish between the individual sections of the reports (forecasts vs. economic policy recommendations), specific fields of economic policy, whether minority votes were submitted in the main text or in footnotes, and whether votes favored demand-oriented policies. We have self-compiled a dataset on minority votes for the period 1950-2014. We also elaborate on participation in the Joint Economic Forecast since 2007, when the German government introduced procurement by tender for the Joint Economic Forecast.

\section{JOINT ECONOMIC FORECAST AND GERMAN ECONOMIC RESEARCH INSTITUTES}

\section{Joint Economic Forecast}

Leading Economic Research Institutes have prepared the Joint Economic Forecast for the Federal Ministry of Economic Affairs since 1950. Establishing the Joint Economic Forecast was among the first actions of the Working Group of German Economic Research Institutes

\footnotetext{
${ }^{3}$ Confirming an institute's identity may well be expressive [Brennan and Lomasky 1993, Hillman 2010 ].

${ }^{4}$ Potrafke [2013] investigates minority votes in the German Council of Economic Experts. The results show that council members nominated by the trade unions took different positions than their colleagues.
} 
which was founded on March 15, 1949 [Marquardt 1979]. Until 2006, the same institutes prepared the reports: the German Institute for Economic Research in Berlin (DIW), the Hamburg Archive of International Economics (HWWA, since the end of 1952), the ifo Institute in Munich, the Kiel Institute for the World Economy (IfW), and the RheinischWestfälisches Institut für Wirtschaftsforschung in Essen (RWI). The Institute for Agricultural Market Research (today Johann Heinrich von Thünen Institute) participated until $1970 .^{5}$ The Halle Institute for Economic Research (IWH) has participated since 1993. The HWWA closed at the end of 2006 and does not participate any longer.

The Federal Ministry of Economic Affairs has put participation in the Joint Economic Forecast out to tender since 2007 to increase competition between the institutes. ${ }^{6}$ Applicants do not need to be German but sound knowledge of German institutions is required and German is the working language. The Federal Ministry of Economic Affairs awards threeyear contracts to four consortia. The DIW did not participate between autumn 2007 and spring 2013, and the IfW has not participated since autumn 2013. The following institutes temporarily acted as partners in consortia since 2007: the Center for European Economic Research in Mannheim (ZEW), the Institute for Advanced Studies in Vienna (IHS), the Austrian Institute of Economic Research in Vienna (WIFO), Kiel Economics, the KOF Swiss Economic Institute at ETH Zurich, and the Macroeconomic Policy Institute in Düsseldorf (IMK).

Drafting the Joint Economic Forecast lasts several weeks. Preparatory talks among business cycle department heads of each institute take place in the Federal Ministry of

\footnotetext{
${ }^{5}$ We exclude the Institute for Agricultural Market Research from our dataset because it did not submit any minority vote while participating.

${ }^{6}$ Competition between economic research institutes and with other organizations (e.g. consultants, OECD, central and commercial banks) has increased in recent years [Döhrn 2005, Döhrn and Schmidt 2011].
} 
Finance, the Bundesbank or the European Central Bank. ${ }^{7}$ The core meetings last about two and a half weeks nowadays.

The first part of the Joint Economic Forecast investigates international economic performance, fiscal policy, and the monetary policy framework. The second part on Germany contains forecasts of main economic aggregates such as real GDP growth. The institutes' individual growth forecasts are combined and made consistent. ${ }^{8}$ The third part contains recommendations for economic policy.

The Joint Economic Forecast is a reference for the government's projections of economic trends. The institutes investigate and forecast the economic situation and give recommendations for economic policy. ${ }^{9}$ The Joint Economic Forecast has a similar purpose as the yearly report of the Council of Economic Experts. ${ }^{10}$ The federal government takes the results of the Joint Economic Forecast into account when it publishes its growth expectations one week after the Joint Economic Forecast. ${ }^{11}$

The Joint Economic Forecast is helpful for policy-makers because its recommendations generally are based on a consensus among institutes with different identities. ${ }^{12}$ But for a long time the institutes advocated different economic approaches and theories [Eichel 2000]. ${ }^{13}$ Minority votes show that the institutes did not always agree. Minority votes appear in the main text when central issues are touched upon, or in footnotes. Given high levels of uncertainty when making projections, e.g. of economic growth, it is

\footnotetext{
${ }^{7}$ Representatives of the Council of Economic Experts and the Federal Statistical Office also participate in preparatory talks in autumn.

${ }^{8}$ A joint model was developed in the 1970s and each institute was responsible for different parts. Institutes however soon developed their own models [Marquardt 1979]. Döpke [2001] shows that the German research institutes' expectations in the Joint Economic Forecast are not rational.

${ }^{9}$ See press release of the Federal Ministry of Economic Affairs, June 3, 2010. Bretschneider et al. [1989] show that forecast accuracy increases when independent forecasts from competing agencies are combined.

${ }^{10}$ The Council of Economic Experts though focuses less on forecasting but rather on discussing basic allocative and distributive issues [Schmahl 2000].

${ }^{11}$ The Joint Economic Forecast influences economic policy. For instance, when the exchange rate of the Deutsche Mark was floated in May 1971, the Joint Economic Forecast had recommended doing so.

12 The Federal Ministry of Economic Affairs explicitly demands results and recommendations that are supported by all participants (see notice of award 2013). Minority votes deviate from such a concept.

${ }^{13}$ For details on how econometric modelling differs across institutes, see the Joint Economic Forecast in spring 2008 [ifo Schnelldienst 8/2008, p. 50]. Carstensen et al. [2011] show that the optimal choice of forecast indicators depends on the specific forecast situation.
} 
conceivable that finding a consensus is easier regarding forecasts than regarding economic policy recommendations. Most minority votes are hence submitted in the sections on economic policy [Nierhaus 2002]. When minority votes are submitted, politicians may delay economic policy reforms because experts tend to disagree on economic policy issues [Filusch 1992, Jones and Cullis 1993]. ${ }^{14}$ Investigating how institutes submitted minority votes is hence an important issue.

\section{Ideological Identities of Economic Research Institutes}

The leading German economic research institutes pursue scientific research and contract research and give policy advice. Contract research is applied research that aims to help contractors make decisions on economic policy.

Ideological identities are attributed to different institutes [Döpke 2000, Antholz 2005]. We use three indicators to describe ideological identity: we examine news coverage to describe public opinion regarding institutes, we investigate the minority votes directly, and we describe what German economists have written about the ideological identities of individual institutes. $^{15}$ The content of minority votes often describes ideological beliefs. Ideological identities may well have changed over the years, yet the public debate still attributes ideological identities to institutes based on discussions in the last decades. ${ }^{16}$ Ideological identities can be distinguished between Keynesian/demand-oriented and neoclassical/supplyoriented.

The DIW has a reputation as demand-oriented (Handelsblatt 2012: “The DIW traditionally stands in the left political corner." ${ }^{17}$ Die Zeit 1988: “Traditionally the DIW is put

\footnotetext{
${ }^{14}$ The news coverage of a minority vote in the Joint Economic Forecast in spring 2014 was: “The DIW did not want to join the other institutes in criticizing the government's policies and wrote a minority vote - which will most likely be heard, especially in the government" [Handelsblatt, April 10, 2014].

${ }^{15}$ Yet, news coverage may well exaggerate ideological positions [Zimmermann 2008].

${ }^{16}$ Cf. “Institute im Umbruch”, Frankfurter Allgemeine Zeitung, July 20, 2012.

${ }^{17}$ See "Deutschland hat einen schwierigen Part”, Handelsblatt, August 10, 2012.
} 
somewhere close to the Social Democrats.”"18). Minority votes confirm this ideological identity. In autumn 2005 the DIW voted for more active fiscal policy "even though this may delay consolidation in the short-run”. ${ }^{19}$ In spring 1999 the DIW disagreed with the other institutes who deemed wage agreements as too high. ${ }^{20}$

Newspapers have called the IfW "liberal"21 and representing "supply-side policy". 22 Minority votes confirm this ideological identity. In autumn 2001, for instance, the IfW wanted to continue fiscal consolidation whereas the other institutes found such fiscal policy too restrictive. $^{23}$

The ifo Institute also has a supply-side identity: it has been called "businessfriendly”, ${ }^{24}$ and sometimes proximity to the conservative CSU party is suggested. ${ }^{25}$ In a minority vote in spring 1981, the ifo Institute calls for more restrictive monetary policy to counteract the "danger that trade unions achieve higher wages”. ${ }^{26}$

The RWI has also been called "close to business"27 and as representing "supplyoriented economic policy”. ${ }^{28}$ This ideological identity is in line with the minority votes that were submitted: In autumn 1980, for instance, the institute advocated "limiting the increase of government spending”.

The IWH does not have a clear ideological identity in the media. ${ }^{29}$ The minority votes imply a demand-side identity. The reason may be that the IWH is the only participating institute in Eastern Germany and has advocated an active role for the state to accelerate economic convergence. In spring 1996 the institute favored a less restrictive fiscal policy to

\footnotetext{
${ }^{18}$ See “Bonner Kulisse”, Die Zeit, December 30, 1988.

${ }^{19}$ See DIW Wochenbericht 43/2005, p. 647.

${ }^{20}$ See Wirtschaft im Wandel 6/1999, p. 45.

${ }^{21}$ See "Schröders Regierungsprogramm bricht mit Tabus der Partei”, Die Zeit, March 05, 1998.

22 See “Das Kieler Debakel”, Handelsblatt, May 28, 2013.

${ }^{23}$ See Wochenbericht des DIW 43/2001, p. 705.

${ }^{24}$ See "Gewinner ohne Mumm”, Die Zeit, February 17, 1984.

${ }^{25}$ See “Das Kieler Debakel”, Handelsblatt, May 28, 2013, and “DIW attackiert Ifo-Institut: `CSU-Nähe und fragwürdige Methoden'”, Spiegel Online, April 25, 2001.

${ }^{26}$ See ifo Wirtschaftskonjunktur 1981, volume 4, p. 15.

${ }^{27}$ See “2009 droht Bundesrepublik schlimmste Rezession”, Die Welt, December 10, 2008.

${ }^{28}$ See “Zur Prognose verdammt”, Die Zeit, October 31, 1980.

${ }^{29}$ In a press article, the institute is called "close to the CDU party [see "Sieger heißt PDS”, Die Zeit, July 28, 1995]. Contents of minority votes do not confirm a rightwing position.
} 
finance the East German catching-up process. ${ }^{30}$ The IWH submitted all minority votes until 2006 together with the DIW. Further demand-oriented minority votes were submitted from 2007 to 2010 while in a consortium with the (Union related) IMK. In spring 2008, spring 2009 and autumn 2009 the consortium disagreed with the other institutes, which opposed a general minimum wage.

The HWWA did not have a clear ideological identity in the media either. The minority votes imply a supply-side identity. In 1955, the HWWA demanded more investment and lower taxes in a joint minority vote with the IfW. ${ }^{31}$ In autumn 2003, the HWWA, the ifo Institute and the IfW rejected deficit-financed fiscal policy. ${ }^{32}$

Some economists have also commented on differences in identities of institutes. Döpke (2000) describes, for example, the Kiel Institute for the World Economy (IfW) as having a reputation for monetarist views, whereas the German Institute for Economic Research in Berlin (DIW) has the reputation of having Keynesian/demand-side views. Langfeldt and Trapp [1988, p. 430] maintain "the DIW has a pronounced Keynesian orientation. The Ifo-Institute combines Keynesian analysis with surveys on business sentiments and on investment plans, while Essen, Hamburg, and Kiel have a neoclassical orientation in common.”

Consequently, the DIW was for a long period the only demand-oriented institute that participated in the Joint Economic Forecast. Even after the IWH joined the group, the two institutes were the minority. From 2007 to 2010, the IWH/IMK consortium was the only demand-oriented participant. It is conceivable that, given their minority positions, the DIW and the IWH would have revealed their dissenting opinion in minority votes. All other institutes take a neoclassical/supply oriented approach to modeling the economy. The

\footnotetext{
${ }^{30}$ See ifo Wirtschaftskonjunktur 1996, volume 4, p. 20.

${ }^{31}$ See Gemeinschaftsdiagnose der Bibliothek des IfW an der Universität Kiel, 1955/56, p. 10.

${ }^{32}$ See DIW Wochenbericht Nr. 43/2003, p. 682.
} 
attitudes regarding economic policy clearly differed between DIW/IWH and the other institutes.

\section{DATA AND DESCRIPTIVE ANALYSIS}

To compile the data set on minority votes we examined the Joint Economic Forecasts over the period 1950-2014. Since the Joint Economic Forecast is published twice a year, our data set covers 129 reports. In 1964 only one report was issued, since in this year the publication dates changed from mid-year and end of the year to spring and autumn. For every Joint Economic Forecast we recorded the participating economic research institutes, and since 2007 the participating consortia. We counted the minority votes that were submitted by each participating institute. When two institutes jointly submitted a minority vote, we coded a vote for each of the participating institutes. "Split votes" (one half of the institutes has a different opinion than the other half) were not interpreted as minority votes. ${ }^{33}$

We examined whether the minority vote is in the main text body or in the form of a footnote and thus distinguish whether the minority vote concerns a fundamental topic or a rather subordinate question [Nierhaus 2002]. Footnotes referring to a minority vote in the text body of the same report were not counted as individual minority votes (this occurred several times in autumn 2011 concerning the role of the ECB and EFSF). For the reports starting in the second half of 2007, where a large and a small institute form a consortium, minority votes were counted for the bigger partner. Such coding is consistent since none of the cooperation partners participated in the Joint Economic Forecast before 2007 and there was no cooperation between two large institutes. ${ }^{34}$ The year 2007 is however a turning point that we account for in the econometric analysis.

\footnotetext{
${ }^{33}$ Split votes occurred in autumn 2003 regarding the tax reform and in 2012 regarding the role of the ECB in the economic crisis.

${ }^{34}$ The KOF has cooperated with the ifo Institute since autumn 2007, the ZEW cooperated from autumn 2010 until spring 2013 with the IfW, the IMK and the WIFO cooperated from autumn 2007 until spring 2010 with the
} 
Table 1 shows that the DIW submitted the most minority votes, 0.54 votes on average per participation. The IWH submitted 0.34 minority votes on average per participation. The other institutes (RWI, ifo, IfW and HWWA) submitted much fewer minority votes. The Keynesian/demand-oriented institutes submitted more minority votes than the supply-oriented institutes.

Table 1: Number of minority votes of economic research institutes

\begin{tabular}{llrr}
\hline Institute & Participations & $\begin{array}{l}\text { Number of } \\
\text { minority votes }\end{array}$ & \multicolumn{2}{c}{$\begin{array}{l}\text { Minority votes per } \\
\text { participation }\end{array}$} \\
\hline DIW & $117(1950 / 1-2007 / 1$, & 63 & 0.54 \\
& $2013 / 1-2014 / 2)$ & & \\
HWWA & $108(1952 / 2-2006 / 2)$ & 3 & 0.03 \\
ifo & $129(1950 / 1-2014 / 2)$ & 15 & 0.12 \\
IfW & $126(1950 / 1-2013 / 1)$ & 15 & 0.12 \\
IWH & $44(1993 / 1-2014 / 2)$ & 15 & 0.34 \\
RWI & $129(1950 / 1-2014 / 2)$ & 22 & 0.17 \\
\hline
\end{tabular}

Source: Own calculations.

Figure 1 shows how minority voting evolved over time. For every year we show the number of minority votes that were submitted up to that point. The DIW submitted most minority votes until 2007; the other institutes submitted much fewer minority votes. Especially before 1970 and during the German unification only few or no minority votes were submitted.

The DIW submitted many votes between 1981 and 1988 under Hans-Jürgen Krupp’s presidency (1979-1988). ${ }^{35}$ Minority votes dealt with manifold economic policy issues and show that the demand-oriented DIW and the supply-oriented IfW under Herbert Giersch had different economic-policy positions. The DIW submitted more minority votes since 2002 and promoted in many cases a more expansive fiscal policy. The IWH also submitted many votes

IWH, Kiel Economics has cooperated since autumn 2010 with the IWH, the IHS has cooperated since autumn 2007 with the RWI and the WIFO has cooperated since autumn 2013 with the DIW.

${ }^{35}$ Hans-Jürgen Krupp, who was nominated by the trade unions to become a member in the German Council of Economic Experts, often expressed his differing opinion in the reports of the German Council of Economic Experts [Potrafke 2013]. 
since 2002, especially in favor of minimum wages and more expansive fiscal policies. During the short period from 1979 to 1983 the IfW submitted many minority votes concerning the then restrictive monetary policy. The voting behavior of the RWI stands out in the period between 1975 and 1978, when many votes concerned the problem of too high wage agreements.

Figure 1: Cumulative number of minority votes

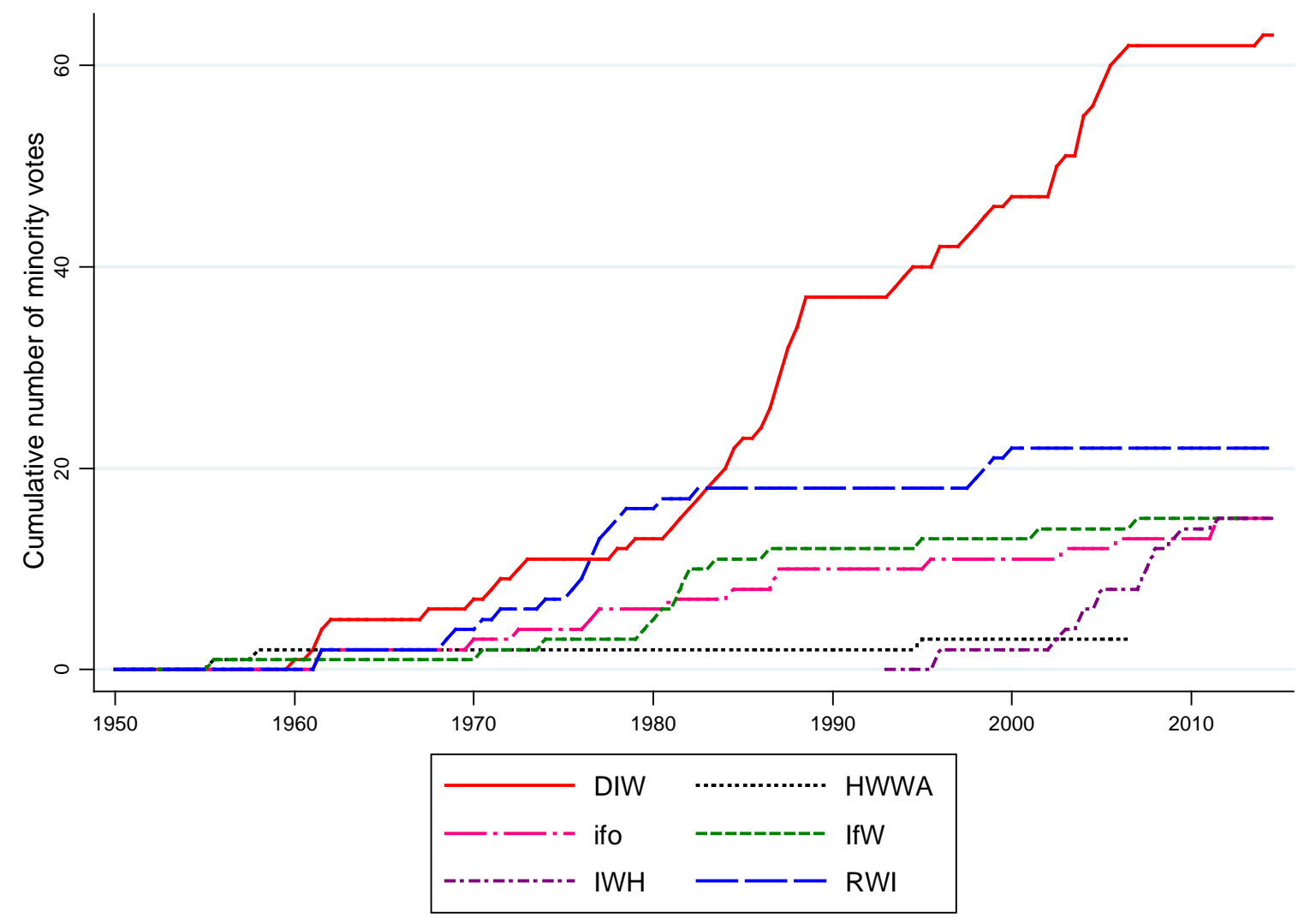

Source: Own compilation.

We examine whether minority votes occurred in the text body or in footnotes. Figure 2 shows the results. Most institutes placed minority votes rather in the text body than in footnotes. Only the IWH submitted more minority votes in the footnotes than in the text body. 
Figure 2: Distribution of minority votes between text body and footnotes

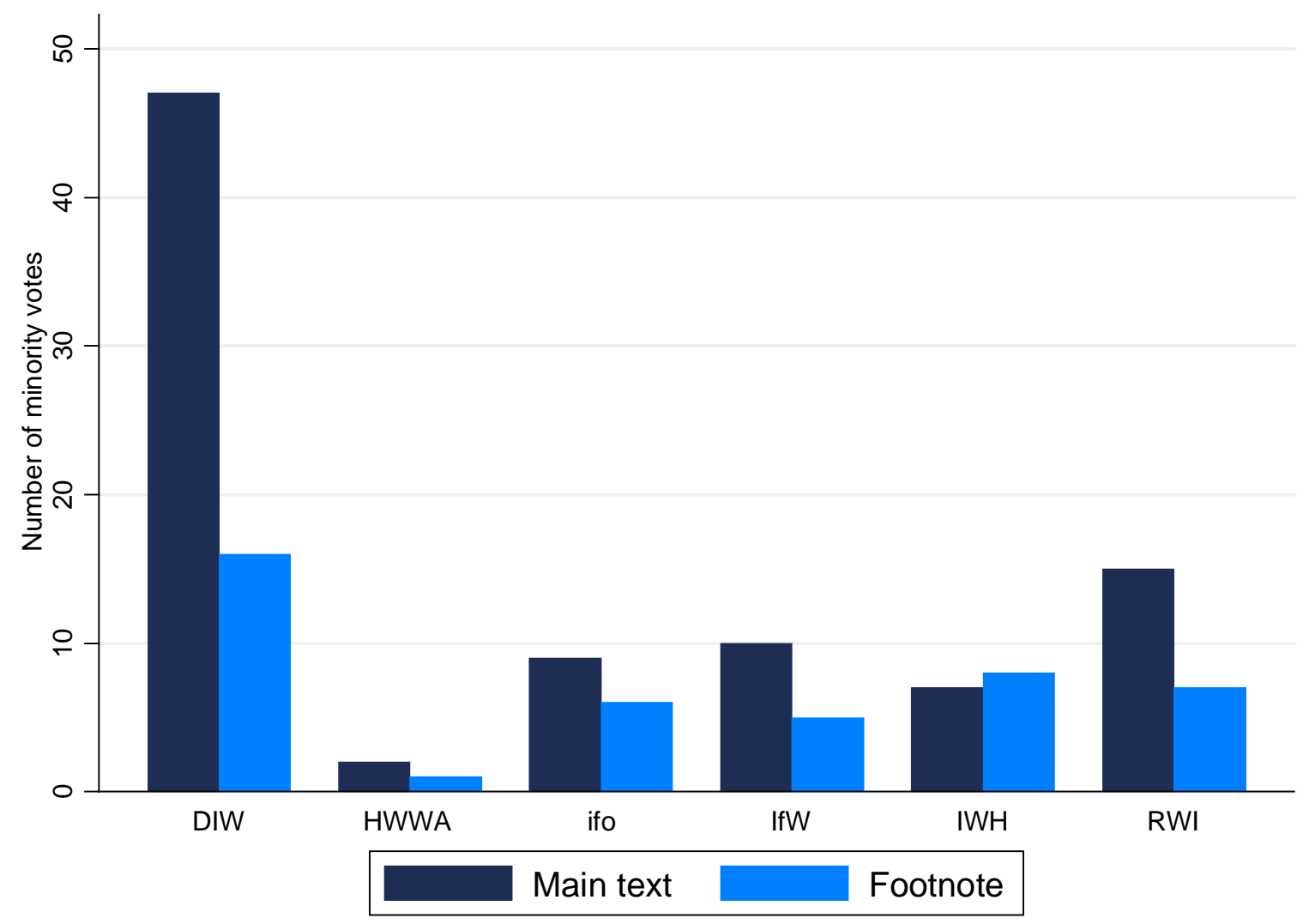

Source: Own compilation.

We examine in which section of the Joint Economic Forecast minority votes appeared. ${ }^{36}$ Most minority votes appeared in the economic policy section (see Figure 3). The forecasting sections (world economy / German economy) were less controversial. ${ }^{37}$ Only the IfW submitted more minority votes in the forecast sections than in the economic policy section.

\footnotetext{
${ }^{36}$ In exceptional cases a minority vote refers to several sections of the report.

${ }^{37}$ All minority votes concerning forecasts are included in the section German economy. It is unclear whether minority forecasts are better than forecasts of the majority of institutes [Antholz 2005].
} 
Figure 3: Distribution of minority votes between sections of the reports

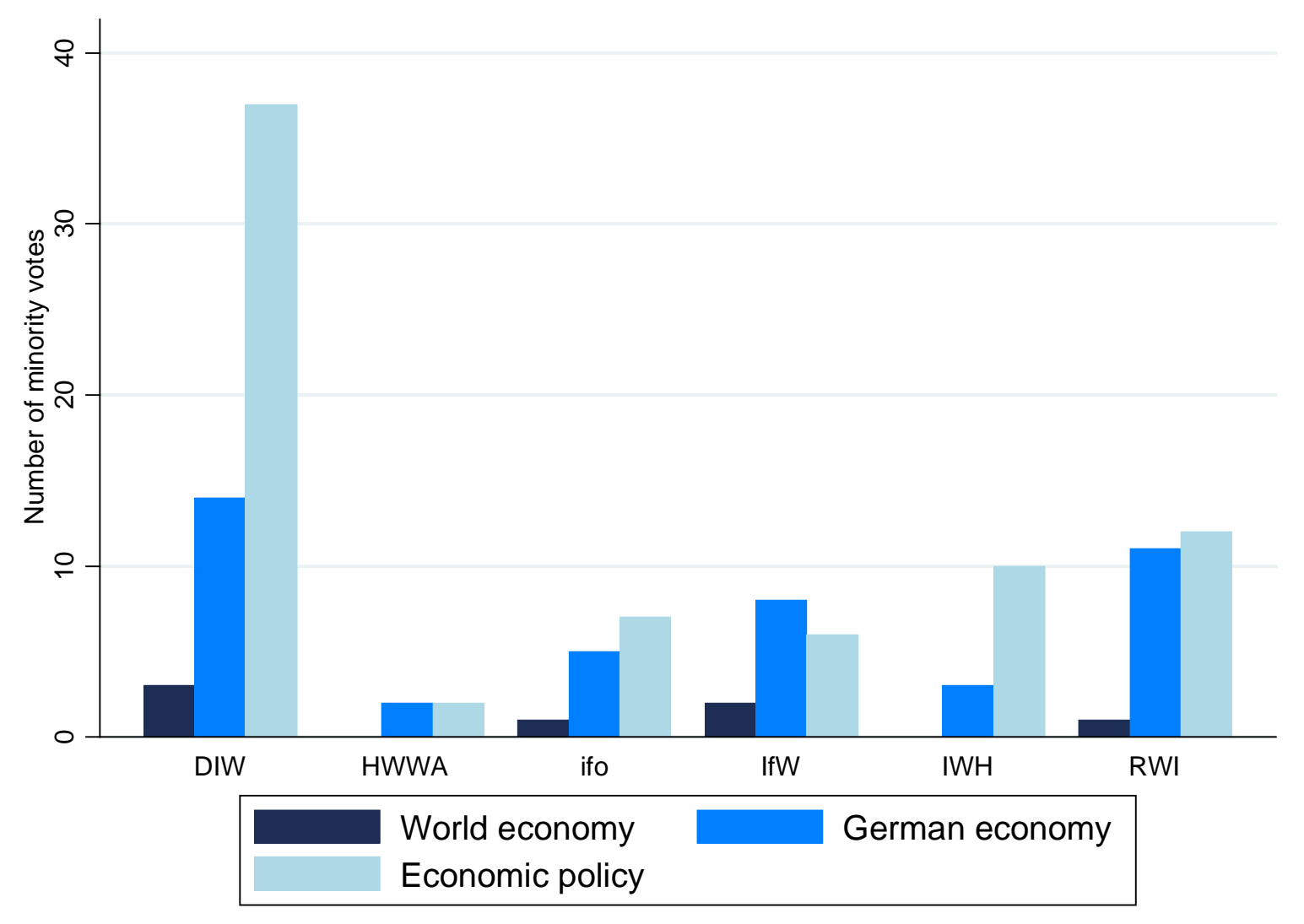

Source: Own compilation.

Focusing on the economic policy section, the results show that the DIW and the IWH mostly addressed fiscal policy issues in their minority votes (see Figure 4). ${ }^{38}$ The HWWA, ifo, IfW and the RWI submitted more minority votes on monetary policy issues than fiscal policy issues. The DIW, the IWH and the RWI submitted more minority votes concerning labor market policy than the other institutes.

\footnotetext{
${ }^{38}$ One minority vote can address two or three different economic policy fields.
} 
Figure 4: Distribution of minority votes between economic policy fields

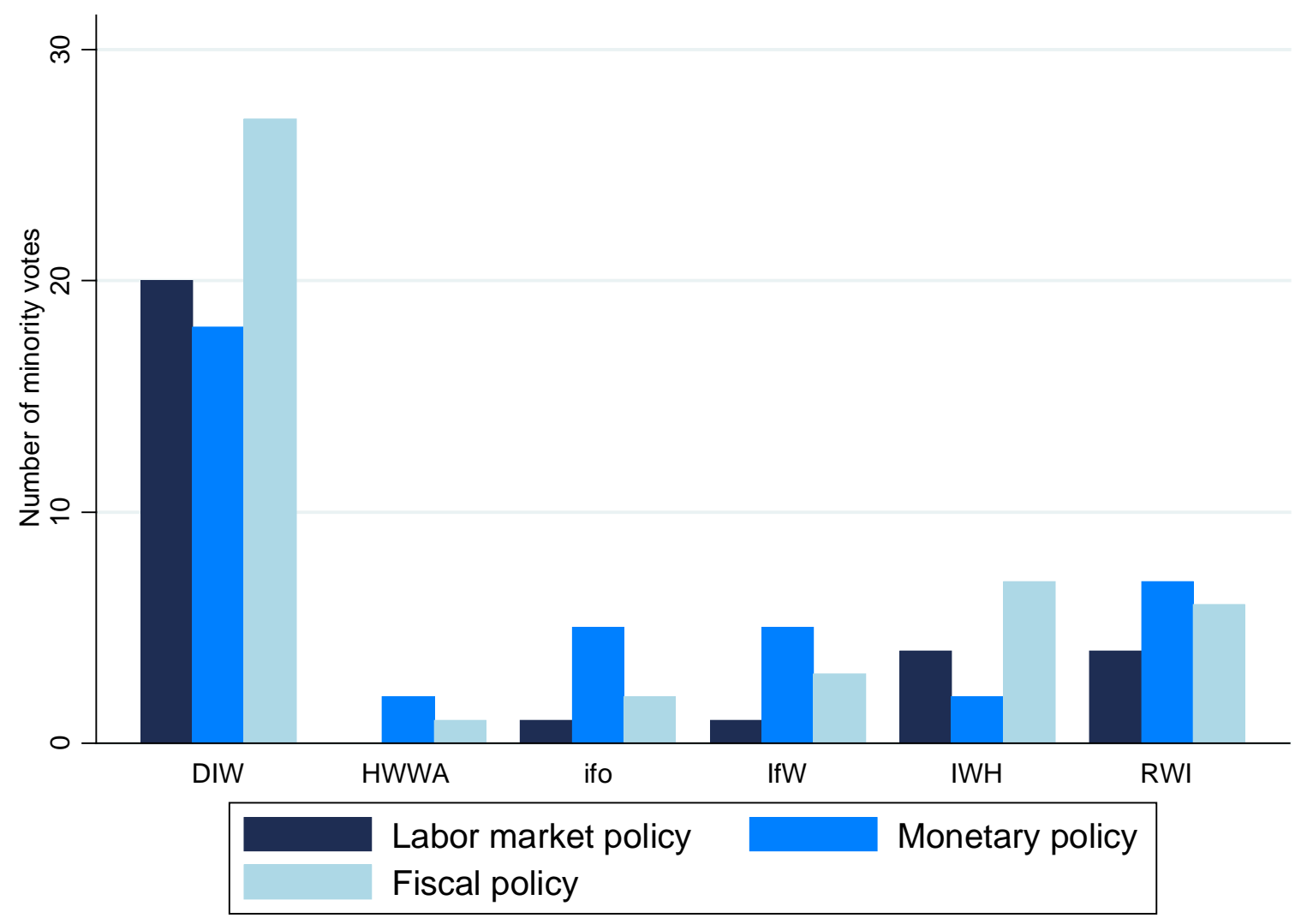

Source: Own compilation.

We also investigate the content of the minority votes in the economic policy section. We examine whether minority votes are demand-oriented. A minority vote is demand-oriented if it favors a larger size and scope of government, higher wages, or lower interest rates, or more fiscal stimulus. Figure 5 shows that the DIW and the IWH submitted nearly all demandoriented minority votes. 
Figure 5: Distribution of demand-oriented minority votes

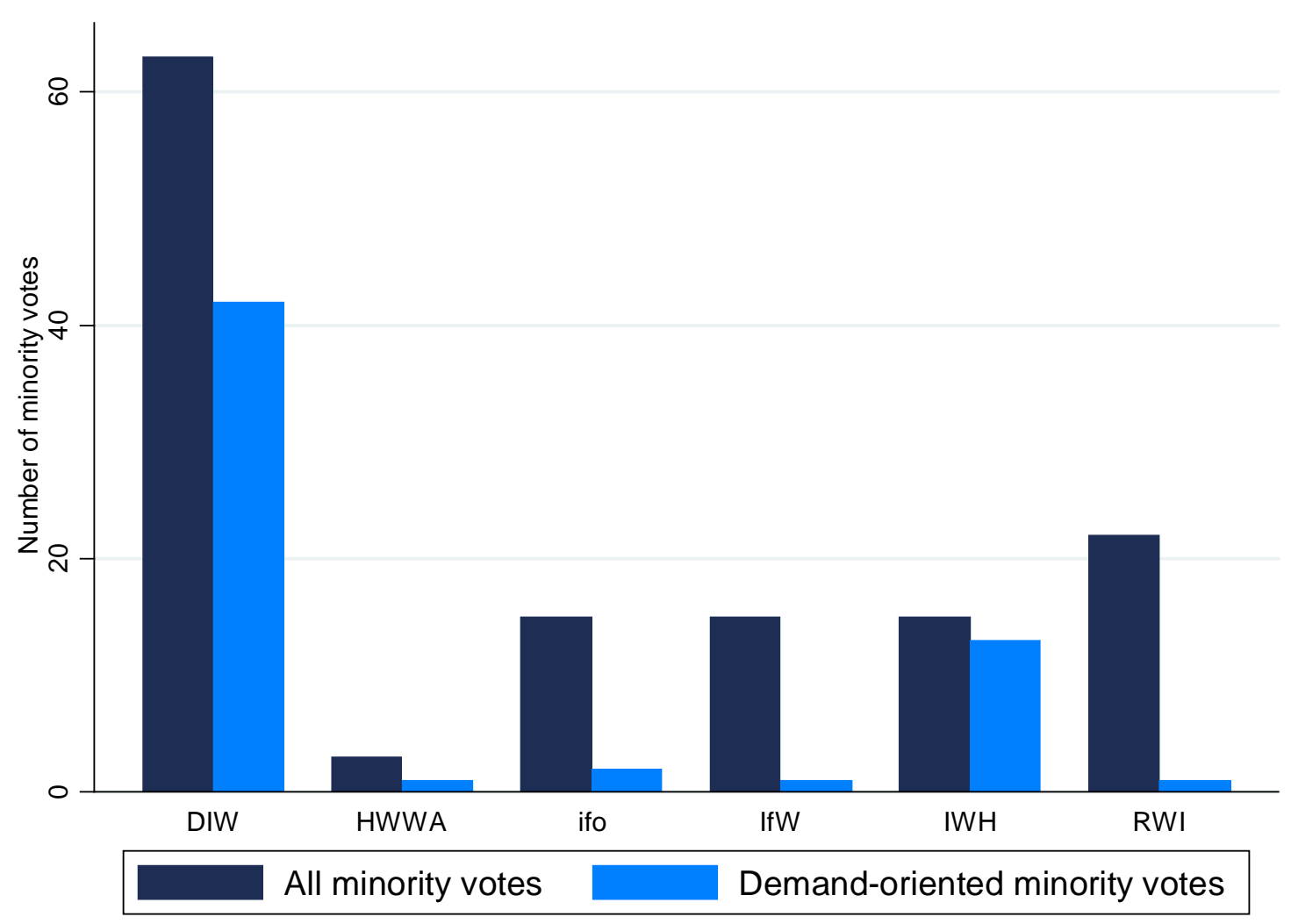

Source: Own compilation.

In the following section we investigate minority voting using an econometric model. Macroeconomic variables that could have influenced voting behavior are not part of our descriptive analysis.

\section{ECONOMETRIC ANALYSIS}

\section{Econometric Model}

Our basic count data model has the following form:

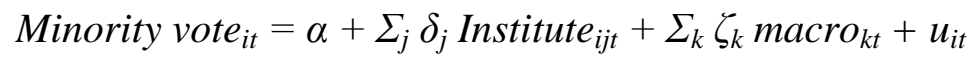

with $i=1, \ldots, 6 ; j=1, \ldots, 5 ; k=1, \ldots, 10 ; t=1, \ldots, 129$. 
The dependent variable Minority vote $_{i t}$ describes the number of minority votes that institute $i$ submitted in report $t$. As explanatory variables we include a dummy variable for each of the participating institutes. The reference institute in the estimations is the RWI, therefore the corresponding variable is not included in the model. Which reference institute we chose does not change the inferences. As macroeconomic control variables macro $_{k t}$ we use the annual inflation rate, unemployment rate and growth rate of real GDP (Source: Federal Statistical Office). ${ }^{39}$ We also include a dummy variable which assumes the value one in recession years (years with negative annual real GDP growth), to account for systematic errors in growth expectations over the business cycle [Dovern and Jannsen 2015]. We also control for the ideology of the federal government by including a variable in our model that takes the value zero for a leftwing government (SPD/FDP or SPD/Greens), the value one for a rightwing government (CDU/CSU or CDU/CSU/FDP) and the value 0.5 for a grand coalition government (CDU/CSU/SPD). We use decade dummy variables (the reference category are the years after 2010) to control for external shocks. Table 2 shows descriptive statistics of all variables.

We estimate a Poisson model with robust standard errors. Our data fulfills the distribution assumptions: mean (0.204) and variance (0.279) of our dependent variable are almost equal. $^{40}$

\section{Results}

Table 3 shows the regression results as incidence rate ratios. In column (1) we only include the institute dummies. In columns (2) to (5) we include the recession variable, inflation rate, unemployment rate, and a variable for government ideology separately and jointly as control variables. In column (6) we also control for time-specific shocks with decade dummy

\footnotetext{
39 The data for GDP growth rate in the year 1950 is taken from the Maddison Project (http://www.ggdc.net/maddison/Historical_Statistics/horizontal-file_02-2010.xls, last accessed 18.05.2015).

${ }^{40}$ Goodness of fit tests do not reject the hypothesis that the distribution assumptions are fulfilled.
} 
variables. In column (7) we replace the recession variable by the growth rate of GDP. In column (8) we replace the decade dummy variables by a linear and quadratic time trend.

The regression results show that the DIW and the IWH (in some specifications) submitted more and the HWWA fewer minority votes than the RWI (reference institute). The incidence rate ratios of the DIW and the HWWA are always statistically significant at the $1 \%$ level. For the IWH the incidence rate ratio of the institute dummy is only significant at the $10 \%$ level in five specifications. The incidence rate ratio indicates the factor by which the rate of minority voting varies between the considered category and the reference category. The results show, for example, that the rate of minority voting of the DIW in column (6) corresponds to $306 \%$ of the rate of minority voting of the RWI. The ifo Institute submitted minority votes at a rate of $68 \%$ of the RWI's rate in each report, and the IfW $69 \%$ of the RWI's rate in each report. The IWH submitted minority votes at a rate of $206 \%$ and the HWWA at a rate of $15 \%$ of the RWI's rate in each report. The econometric results correspond with the results of the descriptive analysis.

The incidence rate ratios of the control variables show that the institutes submitted fewer minority votes when inflation was high. The incidence rate ratio of the inflation rate is statistically significant at the $10 \%$ and $5 \%$ level in columns (6) and (7). It is conceivable that the demand-oriented DIW advocated quite high inflation rates: The Phillips curve describes a tradeoff between unemployment and inflation. Blue collar workers, who are supposed to be positively disposed toward demand-oriented policies, benefit from low unemployment and care less about high inflation than, for example, wealthy entrepreneurs who are supposed to be positively disposed toward market-oriented policies. As a consequence, the DIW submitted fewer minority votes when inflation was high (see also Table 5). The incidence rate ratios of the recession variable, the unemployment rate, and the GDP growth rate do not turn out to be statistically significant. In columns (4), (5), and (8) the coefficient of government ideology is statistically significant at the $1 \%$ level. Under rightwing governments fewer minority votes 
were submitted. The rate of submitting minority votes follows an inverted U-shaped curve over time. The linear and quadratic time trends are statistically significant in column (8) and indicate that the incidence rate was highest in spring 1987.

We investigate the reasons of dissent, i.e. the content of the minority votes. We use a new dependent variable measuring the number of demand-oriented votes in the economic policy section. Table 4 shows the results of estimating our baseline regressions with the new dependent variable. The incidence rate ratios of the DIW and the IWH are larger than in the baseline regressions and statistically significant at the $1 \%$ level in all specifications. The incidence rate ratio of the inflation rate is smaller than one and statistically significant in column (2). The incidence rate ratio of the unemployment rate is larger than one and statistically significant in some specifications. The incidence rate ratios of the recession variable and the government ideology variable do not turn out to be significant in any specification. The incidence rate ratio of the GDP growth rate is smaller than one and statistically significant at the $1 \%$ level in column (7). Demand-oriented minority votes were hence less likely to occur when GDP was growing rapidly. The results show that the results in Table 3 are mainly driven by demand-oriented minority votes that favor a larger size and scope of government.

We estimate the count data model separately for each institute and test whether the control variables such as the economic situation or government ideology influenced minority votes. We also include a dummy variable which assumes the value one for reports after autumn 2007 when the federal government put participation out to tender, introduced the possibility to form consortia and limited the number of participants to four. We cannot consider the HWWA because the HWWA submitted too few minority votes. We control for time-specific effects with linear and quadratic time trends (as in column (8) in the standard specification) instead of decade dummies because of the lower number of observations. Column (1) in Table 5 shows that the DIW had a low rate of submitting minority votes in 
times of high inflation. The incidence rate ratio of the inflation rate is statistically significant at the $1 \%$ level. The numerical meaning of the incidence rate ratio is that when the inflation rate increased by one percentage point, the DIW's rate of submitting minority votes decreased by $18 \%$. The rate of submitting minority votes of the RWI also decreased when the inflation rate was high. The rate of submitting minority votes of the IWH increased when the unemployment rate was high. Under rightwing governments the IfW and the RWI submitted fewer minority votes. The incidence rate ratio is statistically significant at the $10 \%$ level for the IfW and at the $1 \%$ level for the RWI. The IfW and the RWI did not submit any minority votes in the procurement by tender period (the incidence rate decreased by $100 \%$ ). The incident rate ratios are statistically significant at the $1 \%$ level. The IWH's rate of submitting minority votes increased by a factor of 35 in the procurement by tender period. The incidence rate ratio is statistically significant at the $1 \%$ level. It is conceivable that minority votes submitted from autumn 2007 until spring 2010 were attributed to the IMK which cooperated with the IWH in this time period. The result (Table 3) that the IWH submitted significantly more minority votes than the RWI may hence have been influenced by the participation of the Union related IMK. The effects of the inflation rate, GDP growth rate and government ideology are similar to the results in the baseline specification.

\section{Robustness Checks}

We test the robustness of our results in several ways. Since the Poisson model exhibits quite strict distribution assumptions, we also estimate a negative binomial model, a zero-inflated Poisson model, and a zero-inflated negative binomial model. Inferences regarding the institute variables do not change.

We test whether the results differ when we use real time data of macroeconomic variables, to account for the information set that was available to the participants at the time of writing the reports. We use inflation and real GDP growth data from the reports, referring 
to the year when the report was published. The sample starts in 1962, because no data on inflation and real GDP growth were included in the first reports. ${ }^{41}$ Inferences regarding the voting behavior of the DIW do not change. The coefficient of the IWH loses statistical significance in some specifications. Inferences regarding other variables do not change.

Several minority votes by an institute in one report may be closely related and may well be treated as one vote. We replace the count variable with a binary variable, which assumes the value one if an institute submitted a minority vote in a report and zero otherwise. We estimate a Probit model with robust standard errors. Except for the coefficient of the IWH which loses statistical significance, inferences do not change.

We test whether the results depend on whether minority votes occurred in the text body or in footnotes. The findings do not qualitatively change when we consider both types of minority votes separately. The voting behavior of the IWH did not differ from the voting behavior of the RWI when we only take into account minority votes in the text body.

We also test whether the voting behavior of the institutes changes when we examine the individual policy fields. We use Probit models to test whether institutes differed in submitting minority votes. The DIW submitted significantly more minority votes than the RWI, also when separately considering the section economic policy as a whole, as well as its subsections labor market, fiscal and monetary policy. The voting behavior of the IWH did not differ from the voting behavior of the RWI in the monetary policy subsection. The institutes do not differ significantly in the section world economy, which is probably because of the small number of minority votes in the section. In the German economy section only the voting behavior of the HWWA is significantly different from the RWI.

The voting behavior of the institutes may depend on the persons participating, even though no names are included in the reports. The ideological identity of participating persons could be expected to be highly correlated with their institutes’ ideological identity, although

\footnotetext{
${ }^{41}$ Data for the unemployment rate is only included in the reports since 1984.
} 
this need not always be the case. ${ }^{42}$ We therefore test whether the regression results of Table 5 vary, when we also include dummy variables for (i) the acting president of the individual institute or (ii) the head of the business cycle analysis department of the individual institutes. To compile the names of the persons involved we asked the institutes directly and used the annual reports of the institutes. Inferences do not change when we include dummies for the presidents or department heads.

We include other control variables: neither gross wage growth, nor the length of the reports (measured by page numbers) is statistically significant. The budget balance is statistically significant at the $5 \%$ level when included separately, but lacks statistical significance when we include the variable jointly with other explanatory variables. Inferences regarding the other explanatory variables do not change. It is conceivable that the difference between the actual GDP growth rate and the forecasted GDP growth rate from the report, a measure of uncertainty, explains minority votes. We used the forecasts of the GDP growth rate from the respective reports. The observation period, however, shortens as in the 1950s no or only very rough growth forecasts were made. The forecasted GDP growth variable does not turn out to be significant and including it does not change the inferences of the other explanatory variables.

Econometric models can have the problem of reverse causality. In our model, however, reverse causality is unlikely. We rule out the number of minority votes of an institute influencing macroeconomic conditions in the same observation period. The composition of the participating institutes does not depend on the submitted minority votes, at least not until the year 2006, when the participating institutes did not change. But we cannot rule out that minority voting since 2007 played a role for the assignment of the forecasting task by the Federal Ministry of Economic Affairs. Minority votes are thus exogenous in the

\footnotetext{
${ }^{42}$ For example, Ulrich Blum, the president of the IWH over the period 2004-2011, is a member of the CDU party, whereas Udo Ludwig, the institute's head of the business cycle department over the period 1992-2009, received his education in the USSR.
} 
subsample until 2007. The fact that minority votes may affect future participation should be considered when assigning the forecasting task to the consortia. ${ }^{43}$

\section{CONCLUSION}

We have investigated minority voting in the Joint Economic Forecast of German economic research institutes. Our results show that the German Institute for Economic Research (DIW Berlin) submitted by far the most minority votes. In particular, the DIW expressed its distinct opinions in the economic policy part of the report, with the intent of seeking a more influential role of the state in the economy. This finding is in line with the popular belief that the DIW has expressed demand-oriented positions in economic policy-making for a long time and has differed from the other economic research institutes in this respect. The IWH also submitted many minority votes when the institute participated in the Joint Economic Forecast. The minority votes of the IWH mostly concerned demand-oriented positions in economic policy-making and reflect to a great extent the cooperation between the IWH and the Union related IMK from 2007 to 2010. In contrast, the economic policy positions of the HWWA, ifo, IfW and the RWI are similar.

The German economic research institutes have had different ideological identities over the last decades. The minority votes in the Joint Economic Forecast portrayed indicate the extent to which positions of institutes were polarized. The peak of the disagreement between the demand- and supply-oriented institutes occurred in the 1980s. Since then the ideological identities of the institutes seem to have been established in the public debate and have been taken as given from that time on. Minority votes declined over the last years. Polarization of the institutes has become less pronounced. The institutes themselves claim that they do not represent specific economic-policy positions.

\footnotetext{
${ }^{43}$ Laux and Probst [2004] show that analysts may design forecasts strategically to increase the demand for future contracts.
} 
Decision-makers realize when policy advice is driven by a perceived motivation underlying recommendations and the perceived motivation of the adviser determines how decision makers react [Kuang et al. 2007]. The declining polarization of the institutes notwithstanding, when economic research institutes are known to be associated with particular ideological identities, politicians, clients and voters well understand how to assess the policy advice given by the different institutes.

\section{Acknowledgments}

We would like to thank Kai Carstensen, Roland Döhrn, Arye Hillman, Oliver Holtemöller, Wolfgang Nierhaus, Dorothea Schäfer, Joachim Scheide, Christoph M. Schmidt, Heinrich Ursprung, seminar participants at the ifo Institute and an anonymous referee for their helpful comments. Jakob Müller provided excellent research assistance. 


\section{REFERENCES}

Alston, Richard M., J.R. Kearl, and Michael B. Vaughan. 1992. Is There a Consensus Among Economists in the 1990s? American Economic Review, 82(2): 203-209.

Antholz, Birger. 2005. Zur Treffsicherheit von Wachstumsprognosen: prognostizierte und tatsächliche Wachstumsraten des Bruttoinlandsprodukts Deutschlands 1950-2004. Münster: EHA-Verlag.

Austin, D. Andrew, and Nathaniel T. Wilcox. 2007. Believing in Economic Theories: Sex, Lies, Evidence, Trust, and Ideology. Economic Inquiry, 45(3): 502-518.

Brennan, Geoffrey, and Loren Lomasky. 1993. Democracy and Decision: The Pure Theory of Electoral Preference. Cambridge (UK): Cambridge University Press.

Bretschneider, Stuart I., Wilpen L. Gorr, Gloria Grizzle, and Earle Klay. 1989. Political and Organizational Influences on the Accuracy of Forecasting State Government Revenues. International Journal of Forecasting, 5(3): 307-319.

Carstensen, Kai, Klaus Wohlrabe, and Christina Ziegler. 2011. Predictive Ability of Business Cycle Indicators under Test: A Case Study for Euro Area Industrial Production. Jahrbücher für Nationalökonomie und Statistik, 231(1): 82-106.

Coughlin, Peter J. 1989. Economic Policy Advice and Political Preferences. Public Choice, 61(3): 201-216.

De Benedictis, Luca, and Michele Di Maio. 2011. Economists’ View about the Economy: Evidence from a Survey of Italian Economists. Rivista Italiana degli Economisti, 16(1): 11-59.

De Benedictis, Luca, and Michele Di Maio. 2015. Schools of Thought and Economists’ Opinions on Economic Policy. Eastern Economic Journal, forthcoming.

Di Maio, Michele. 2013. Are Mainstream and Heterodox Economists Different? An Empirical Analysis. American Journal of Economics and Sociology, 72(5): 1315-1348.

Döhrn, Roland. 2005. Politikberatung durch wirtschaftswissenschaftliche Forschungsinstitute. Das Beispiel der Gemeinschaftsdiagnose, in Glanz und Elend der Politikberatung, edited by Uwe Jens, and Hajo Romahn. Marburg: Metropolis, 49-58.

Döhrn, Roland, and Christoph M. Schmidt. 2011. Information or Institution? On the Determinants of Forecast Accuracy. Jahrbücher für Nationalökonomie und Statistik, 231(1): 9-27.

Döpke, Jörg. 2000. Haben Konjunkturprognosen einen politischen Bias? Schmollers Jahrbuch, 120(4): 587-620. 
Döpke, Jörg. 2001. Macroeconomic Forecasts and the Nature of Economic Shocks in Germany. International Journal of Forecasting, 17(2): 181-201.

Dovern, Jonas, and Nils Jannsen. 2015. Systematic Errors in Growth Expectations over the Business Cycle. Kiel Working Papers 1989.

Eichel, Hans. 2000. Wissenschaftliche Politikberatung - das Spannungsfeld zwischen Erkenntnis und Entscheidung, in Referate zum Empfang anläßlich der 100. Gemeinschaftsdiagnose der deutschen wirtschaftswissenschaftlichen Forschungsinstitute, edited by Hamburgisches Welt-Wirtschafts-Archiv. Hamburg, 13-19.

Filusch, Bernhard. 1992. Die Konjunkturprognosen der Forschungsinstitute - Anspruch und Wirklichkeit, in Symposium zur Verabschiedung von Dr. Arthur Krumper am 22. Mai 1992, edited by ifo Institut für Wirtschaftsforschung. München, 7-18.

Frisell, Lars. 2005. Consulting Experts with Vested Interests: The Power of Benchmarking. Economics of Governance, 6(2): 113-123.

Fritsche, Ulrich, and Ullrich Heilemann. 2010. Too Many Cooks? The German Joint Diagnosis and Its Production. DEP Discussion Paper, Hamburg.

Fuchs, Victor R., Alan B. Krueger, and James M. Poterba. 1998. Economists’ Views about Parameters, Values and Policies: Survey Results in Labor and Public Economics. Journal of Economic Literature, 36(3): 1387-1425.

Gordon, Roger, and Gordon B. Dahl. 2013. Views among Economists: Professional Consensus or Point-Counterpoint? American Economic Review, 103(3): 629-635.

Hillman, Arye L. 1998. Political Economy and Political Correctness. Public Choice, 96(3-4): 219-239. Reprinted in: Forty Years of Research on Rent Seeking 2-Applications: Rent Seeking in Practice, edited by Roger D. Congleton, Arye L. Hillman, and Kai Konrad. Berlin: Springer, 2008, $791-811$.

Hillman, Arye L. 2009. Public Finance and Public Policy: Responsibilities and Limitations of Government (2nd Ed.). New York: Cambridge University Press.

Hillman, Arye L. 2010. Expressive Behavior in Economics and Politics. European Journal of Political Economy, 26(4): 403-418.

Jones, Philip R., and John G. Cullis. 1993. Public Choice and Public Policy: The Vulnerability of Economic Advice to the Interpretation of Politicians. Public Choice, 75(1): 63-77. 
Kirchgässner, Gebhard. 1996. Ideologie und Information in der Politikberatung: Einige

Bemerkungen und ein Fallbeispiel. Hamburger Jahrbuch für Wirtschafts- und Gesellschaftspolitik, 41(1): 9-41.

Kirchgässner, Gebhard. 1999. On the Political Economy of Economic Policy Advice, in The Transfer of Economic Knowledge, edited by Ernst Mohr, Cheltenham: Edward Elgar, 13-31.

Kirchgässner, Gebhard. 2005. On the Political Economy of Economic Policy Advice - With Applications of Environmental Policy. ZEW Economic Studies, 31(1): 277-298.

Kirchgässner, Gebhard. 2011. Der Ökonom als Berater: Objektivität, Ideologie und Eigeninteresse, in Ökonomik in der Krise, edited by Martin Held, Gisela Kubon-Gilke, and Richard Sturn. Marburg: Metropolis, 219-241.

Kirchgässner, Gebhard. 2013. Zur Rolle der Ökonometrie in der wissenschaftlichen Politikberatung. Perspektiven der Wirtschaftspolitik, 14(1-2): 3-30.

Kirchgässner, Gebhard. 2014. On the Process of Scientific Policy Advice - With Special Reference to Economic Policy. CESifo Working Paper 5144, Munich.

Klein, Daniel B., and Charlotta Stern. 2006. Economists’ Policy Views and Voting. Public Choice, 126(3-4): 331-342.

Kuang, Xi (Jason), Roberto A. Weber, and Jason Dana. 2007. How Effective is Advice from Interested Parties? An Experimental Test Using a Pure Coordination Game. Journal of Economic Behavior and Organization, 62(4): 591-604.

Langfeld, Enno, and Peter Trapp. 1988. Experiences in Macroeconomic Forecasting in the Federal Republic of Germany 1976-1987. Jahrbücher für Nationalökonomie und Statistik, 205(5): 427-442.

Laux, Christian, and Daniel A. Probst. 2004. One Signal, Two Opinions: Strategic Heterogeneity of Analysts’ Forecasts. Journal of Economic Behavior and Organization, 55(1): 45-66.

Mayer, Thomas. 2001. The Role of Ideology in Disagreements among Economists: A Quantitative Analysis. Journal of Economic Methodology, 8(2): 253-273.

Marquardt, Wilhelm. 1979. Chronik des Ifo-Instituts für Wirtschaftsforschung 1949 - 1979, in Dreissig Jahre Wirtschaftsforschung im Ifo-Institut, edited by Wilhelm Marquardt. München, 51-292.

McGann, James G. 2005. Think Tanks and Policy Advice in the US. Foreign Policy Research Institute, Philadelphia. 
Nelson, Robert H. 1987. The Economics Profession and the Making of Public Policy. Journal of Economic Literature, 25(1): 49-91.

Nierhaus, Wolfgang. 2002. Die Gemeinschaftsdiagnose der Wirtschaftsforschungsinstitute. ifo Schnelldienst, 55(8): 40-42.

Potrafke, Niklas. 2013. Minority Votes in the German Council of Economic Experts: A Political Economic Analysis. European Journal of Political Economy, 31(C): 180-187.

Prychitko, David L. ed. 1998. Why Economists Disagree: An Introduction to the Alternative Schools of Thought. Albany: State University of New York Press.

Saint-Paul, Gilles. 2012. Towards a Political Economy of Macroeconomic Thinking. NBER International Seminar on Macroeconomics, 8(1): 249-284.

Schmahl, Hans-Jürgen. 2000. Gemeinschaftsdiagnose - ein Instrument der Politikberatung, in Referate zum Empfang anläßlich der 100. Gemeinschaftsdiagnose der deutschen wirtschaftswissenschaftlichen Forschungsinstitute, edited by Hamburgisches WeltWirtschafts-Archiv. Hamburg, 29-34.

Slembeck, Tilman. 2003. Ideologies, Beliefs, and Economic Advice - A CognitiveEvolutionary View on Economic Policy-Making, in The Evolutionary Analysis of Economic Policy, edited by Pavel Pelikan, and Gerhard Wegner. Edward Elgar: Cheltenham, 128-161.

Zimmermann, Klaus. 2008. Der Berater als Störenfried: wirtschaftswissenschaftliche Politikberatung. Wirtschaftsdienst, 88(2): 101-107. 
Table 2: Descriptive Statistics

\begin{tabular}{|c|c|c|c|c|c|c|}
\hline Variable & Observations & Mean & Std. Dev. & Min & Max & Source \\
\hline $\begin{array}{l}\text { Minority votes (number per } \\
\text { institute and report) }\end{array}$ & 653 & 0.204 & 0.528 & 0 & 4 & $\begin{array}{l}\text { Joint Economic Forecasts/ } \\
\text { own compilation }\end{array}$ \\
\hline $\begin{array}{l}\text { Minority votes in main text } \\
\text { (number per institute and report) }\end{array}$ & 653 & 0.138 & 0.425 & 0 & 3 & $\begin{array}{l}\text { Joint Economic Forecasts/ } \\
\text { own compilation }\end{array}$ \\
\hline $\begin{array}{l}\text { Minority votes in footnote } \\
\text { (number per institute and report) }\end{array}$ & 653 & 0.066 & 0.288 & 0 & 2 & $\begin{array}{l}\text { Joint Economic Forecasts/ } \\
\text { own compilation }\end{array}$ \\
\hline $\begin{array}{l}\text { Minority vote on world economy } \\
\text { (=1 if minority vote on world } \\
\text { economy was submitted) }\end{array}$ & 653 & 0.011 & 0.103 & 0 & 1 & $\begin{array}{l}\text { Joint Economic Forecasts/ } \\
\text { own compilation }\end{array}$ \\
\hline $\begin{array}{l}\text { Minority vote on German } \\
\text { economy (=1 if minority vote on } \\
\text { German economy was } \\
\text { submitted) }\end{array}$ & 653 & 0.066 & 0.248 & 0 & 1 & $\begin{array}{l}\text { Joint Economic Forecasts/ } \\
\text { own compilation }\end{array}$ \\
\hline $\begin{array}{l}\text { Minority vote on economic } \\
\text { policy (=1 if minority vote on } \\
\text { economic policy was submitted) }\end{array}$ & 653 & 0.115 & 0.319 & 0 & 1 & $\begin{array}{l}\text { Joint Economic Forecasts/ } \\
\text { own compilation }\end{array}$ \\
\hline $\begin{array}{l}\text { Minority vote on fiscal policy } \\
(=1 \text { if minority vote on fiscal } \\
\text { policy was submitted) }\end{array}$ & 653 & 0.070 & 0.256 & 0 & 1 & $\begin{array}{l}\text { Joint Economic Forecasts/ } \\
\text { own compilation }\end{array}$ \\
\hline $\begin{array}{l}\text { Minority vote on monetary } \\
\text { policy (=1 if minority vote on } \\
\text { monetary policy was submitted) }\end{array}$ & 653 & 0.060 & 0.237 & 0 & 1 & $\begin{array}{l}\text { Joint Economic Forecasts/ } \\
\text { own compilation }\end{array}$ \\
\hline $\begin{array}{l}\text { Minority vote on labor market } \\
\text { policy (=1 if minority vote on } \\
\text { wage policy or labor market } \\
\text { policy was submitted) }\end{array}$ & 653 & 0.046 & 0.210 & 0 & 1 & $\begin{array}{l}\text { Joint Economic Forecasts/ } \\
\text { own compilation }\end{array}$ \\
\hline $\begin{array}{l}\text { Demand-oriented minority vote } \\
\text { (number per institute and report) }\end{array}$ & 653 & 0.092 & 0.343 & 0 & 2 & $\begin{array}{l}\text { Joint Economic Forecasts/ } \\
\text { own compilation }\end{array}$ \\
\hline Recession & 653 & 0.095 & 0.293 & 0 & 1 & Federal Statistical Office \\
\hline Inflation rate & 653 & 2.463 & 2.057 & -6.19 & 7.75 & Federal Statistical Office \\
\hline Unemployment rate & 653 & 6.862 & 3.941 & 0.7 & 13 & Federal Statistical Office \\
\hline Real GDP growth rate & 653 & 3.463 & 3.408 & -5.1 & 18.9 & Federal Statistical Office \\
\hline $\begin{array}{l}\text { Government ideology } \\
\text { (rightwing) }\end{array}$ & 653 & 0.615 & 0.457 & 0 & 1 & Own compilation \\
\hline Inflation rate (real time) & 538 & 2.917 & 1.843 & -0.5 & 8 & $\begin{array}{l}\text { Joint Economic Forecasts/ } \\
\text { own compilation }\end{array}$ \\
\hline GDP growth rate (real time) & 538 & 2.275 & 2.213 & -6 & 9.5 & $\begin{array}{l}\text { Joint Economic Forecasts/ } \\
\text { own compilation }\end{array}$ \\
\hline Budget balance & 653 & -1.889 & 1.526 & -6.17 & 1.41 & Federal Statistical Office \\
\hline Gross wage growth & 637 & 5.829 & 4.599 & -0.3 & 19.6 & Federal Statistical Office \\
\hline Number of pages & 645 & 27.358 & 19.245 & 6 & 79 & $\begin{array}{l}\text { Joint Economic Forecasts/ } \\
\text { own compilation }\end{array}$ \\
\hline Forecast GDP growth rate & 538 & 2.228 & 2.124 & -6 & 7.9 & $\begin{array}{l}\text { Joint Economic Forecasts/ } \\
\text { own compilation }\end{array}$ \\
\hline
\end{tabular}


Table 3: Regression results. Indicence rate ratios. Reference institute: RWI.

Poisson model with robust standard errors (Huber/White/sandwich standard errors). Dependent variable: Number of minority votes per institute and report.

\begin{tabular}{|c|c|c|c|c|c|c|c|c|}
\hline & (1) & (2) & (3) & (4) & (5) & (6) & (7) & (8) \\
\hline DIW & $\begin{array}{c}3.157^{* * *} \\
(4.34)\end{array}$ & $\begin{array}{c}3.150^{* * *} \\
(4.32)\end{array}$ & $\begin{array}{c}3.175^{* * *} \\
(4.34)\end{array}$ & $\begin{array}{c}3.110^{* * *} \\
(4.38)\end{array}$ & $\begin{array}{c}3.125^{* * *} \\
(4.37)\end{array}$ & $\begin{array}{c}3.057^{* * *} \\
(4.36)\end{array}$ & $\begin{array}{c}3.086^{* * *} \\
(4.37)\end{array}$ & $\begin{array}{c}3.044^{* * * *} \\
(4.34)\end{array}$ \\
\hline HWWA & $\begin{array}{c}0.163^{* * *} \\
(-2.96)\end{array}$ & $\begin{array}{c}0.162^{* * * *} \\
(-2.97)\end{array}$ & $\begin{array}{c}0.165^{* * * *} \\
(-2.93)\end{array}$ & $\begin{array}{c}0.158^{* * * *} \\
(-2.99)\end{array}$ & $\begin{array}{c}0.160^{* * * *} \\
(-2.96)\end{array}$ & $\begin{array}{l}0.150^{* * *} \\
(-3.01)\end{array}$ & $\begin{array}{l}0.151^{* * *} \\
(-2.99)\end{array}$ & $\begin{array}{c}0.149^{* * * *} \\
(-3.06)\end{array}$ \\
\hline ifo & $\begin{array}{c}0.682 \\
(-1.04)\end{array}$ & $\begin{array}{c}0.682 \\
(-1.04)\end{array}$ & $\begin{array}{c}0.682 \\
(-1.03)\end{array}$ & $\begin{array}{c}0.682 \\
(-1.05)\end{array}$ & $\begin{array}{c}0.682 \\
(-1.05)\end{array}$ & $\begin{array}{c}0.682 \\
(-1.05)\end{array}$ & $\begin{array}{c}0.682 \\
(-1.05)\end{array}$ & $\begin{array}{c}0.682 \\
(-1.06)\end{array}$ \\
\hline IfW & $\begin{array}{c}0.698 \\
(-1.01)\end{array}$ & $\begin{array}{c}0.697 \\
(-1.02)\end{array}$ & $\begin{array}{c}0.698 \\
(-1.00)\end{array}$ & $\begin{array}{c}0.697 \\
(-1.04)\end{array}$ & $\begin{array}{c}0.697 \\
(-1.03)\end{array}$ & $\begin{array}{c}0.690 \\
(-1.07)\end{array}$ & $\begin{array}{c}0.690 \\
(-1.07)\end{array}$ & $\begin{array}{c}0.691 \\
(-1.07)\end{array}$ \\
\hline IWH & $\begin{array}{l}1.999^{*} \\
(1.86)\end{array}$ & $\begin{array}{l}2.042^{*} \\
(1.92)\end{array}$ & $\begin{array}{l}1.775 \\
(1.56)\end{array}$ & $\begin{array}{l}1.935^{*} \\
(1.81)\end{array}$ & $\begin{array}{l}1.678 \\
(1.42)\end{array}$ & $\begin{array}{l}2.058^{*} \\
(1.92)\end{array}$ & $\begin{array}{l}2.027^{*} \\
(1.90)\end{array}$ & $\begin{array}{l}1.814 \\
(1.62)\end{array}$ \\
\hline Recession & & $\begin{array}{c}1.013 \\
(0.05)\end{array}$ & $\begin{array}{l}1.017 \\
(0.06)\end{array}$ & $\begin{array}{c}0.860 \\
(-0.56)\end{array}$ & $\begin{array}{c}0.827 \\
(-0.71)\end{array}$ & $\begin{array}{c}0.807 \\
(-0.80)\end{array}$ & & $\begin{array}{c}0.849 \\
(-0.61)\end{array}$ \\
\hline Inflation rate & & $\begin{array}{l}1.027 \\
(0.65)\end{array}$ & & & $\begin{array}{l}1.011 \\
(0.26)\end{array}$ & $\begin{array}{l}0.904^{*} \\
(-1.66)\end{array}$ & $\begin{array}{l}0.886^{* *} \\
(-1.97)\end{array}$ & $\begin{array}{c}0.904 \\
(-1.57)\end{array}$ \\
\hline $\begin{array}{l}\text { Unemployment } \\
\text { rate }\end{array}$ & & & $\begin{array}{l}1.036 \\
(1.41)\end{array}$ & & $\begin{array}{l}1.043 \\
(1.64)\end{array}$ & $\begin{array}{l}1.046 \\
(0.71)\end{array}$ & $\begin{array}{l}1.033 \\
(0.52)\end{array}$ & $\begin{array}{c}0.995 \\
(-0.13)\end{array}$ \\
\hline $\begin{array}{l}\text { Government } \\
\text { ideology } \\
\text { (rightwing) }\end{array}$ & & & & $\begin{array}{l}0.500^{* * *} \\
(-3.28)\end{array}$ & $\begin{array}{l}0.498^{* * *} \\
(-3.42)\end{array}$ & $\begin{array}{c}0.638 \\
(-1.56)\end{array}$ & $\begin{array}{c}0.686 \\
(-1.34)\end{array}$ & $\begin{array}{l}0.552^{* * *} \\
(-2.84)\end{array}$ \\
\hline $\begin{array}{l}\text { GDP growth } \\
\text { rate }\end{array}$ & & & & & & & $\begin{array}{c}0.965 \\
(-0.94)\end{array}$ & \\
\hline $1950 \mathrm{~s}$ & & & & & & $\begin{array}{c}0.348 \\
(-1.23)\end{array}$ & $\begin{array}{c}0.448 \\
(-0.87)\end{array}$ & \\
\hline $1960 s$ & & & & & & $\begin{array}{l}2.194 \\
(1.00)\end{array}$ & $\begin{array}{l}2.191 \\
(1.00)\end{array}$ & \\
\hline $1970 \mathrm{~s}$ & & & & & & $\begin{array}{l}3.625^{*} \\
(1.80)\end{array}$ & $\begin{array}{l}3.975^{*} \\
(1.88)\end{array}$ & \\
\hline $1980 s$ & & & & & & $\begin{array}{l}4.774^{* *} \\
(2.40)\end{array}$ & $\begin{array}{l}4.846^{* *} \\
(2.41)\end{array}$ & \\
\hline $1990 \mathrm{~s}$ & & & & & & $\begin{array}{l}1.485 \\
(0.58)\end{array}$ & $\begin{array}{l}1.545 \\
(0.64)\end{array}$ & \\
\hline $2000 s$ & & & & & & $\begin{array}{l}2.051 \\
(1.04)\end{array}$ & $\begin{array}{l}2.114 \\
(1.11)\end{array}$ & \\
\hline $\begin{array}{l}\text { Linear time } \\
\text { trend } \\
\text { Quadratic time } \\
\text { trend }\end{array}$ & & & & & & & & $\begin{array}{l}1.062^{* * *} \\
(3.70) \\
1.000^{* * *} \\
(-3.38)\end{array}$ \\
\hline Observations & 653 & 653 & 653 & 653 & 653 & 653 & 653 & 653 \\
\hline Pseudo R2 & 0.116 & 0.116 & 0.119 & 0.134 & 0.138 & 0.189 & 0.189 & 0.162 \\
\hline
\end{tabular}

$z$ statistics in parentheses

${ }^{*} p<0.10,{ }^{* *} p<0.05,{ }^{* * *} p<0.01$ 
Table 4: Regression results. Indicence rate ratios. Reference institute: RWI.

Poisson model with robust standard errors (Huber/White/sandwich standard errors). Dependent variable: Number of demand-oriented minority votes per institute and report.

\begin{tabular}{|c|c|c|c|c|c|c|c|c|}
\hline & $(1)$ & $(2)$ & (3) & $(4)$ & (5) & $(6)$ & $(7)$ & $(8)$ \\
\hline DIW & $\begin{array}{c}46.31^{* * * *} \\
(3.80)\end{array}$ & $\begin{array}{c}46.84^{* * *} \\
(3.81)\end{array}$ & $\begin{array}{c}46.89^{* * *} \\
(3.83)\end{array}$ & $\begin{array}{c}46.09^{* * * *} \\
(3.80)\end{array}$ & $\begin{array}{c}46.49^{* * *} \\
(3.83)\end{array}$ & $\begin{array}{c}46.35^{* * * *} \\
(3.84)\end{array}$ & $\begin{array}{c}48.27^{* * *} \\
(3.84)\end{array}$ & $\begin{array}{c}46.39^{* * *} \\
(3.83)\end{array}$ \\
\hline HWWA & $\begin{array}{l}1.194 \\
(0.13)\end{array}$ & $\begin{array}{l}1.225 \\
(0.14)\end{array}$ & $\begin{array}{l}1.249 \\
(0.16)\end{array}$ & $\begin{array}{l}1.178 \\
(0.12)\end{array}$ & $\begin{array}{l}1.222 \\
(0.14)\end{array}$ & $\begin{array}{l}1.137 \\
(0.09)\end{array}$ & $\begin{array}{l}1.183 \\
(0.12)\end{array}$ & $\begin{array}{c}1.141 \\
(0.09)\end{array}$ \\
\hline ifo & $\begin{array}{l}2.000 \\
(0.57)\end{array}$ & $\begin{array}{l}2.000 \\
(0.57)\end{array}$ & $\begin{array}{l}2.000 \\
(0.57)\end{array}$ & $\begin{array}{l}2.000 \\
(0.57)\end{array}$ & $\begin{array}{l}2.000 \\
(0.57)\end{array}$ & $\begin{array}{l}2.000 \\
(0.57)\end{array}$ & $\begin{array}{l}2.000 \\
(0.57)\end{array}$ & $\begin{array}{l}2.000 \\
(0.57)\end{array}$ \\
\hline IfW & $\begin{array}{l}1.024 \\
(0.02)\end{array}$ & $\begin{array}{l}1.025 \\
(0.02)\end{array}$ & $\begin{array}{l}1.020 \\
(0.01)\end{array}$ & $\begin{array}{l}1.022 \\
(0.02)\end{array}$ & $\begin{array}{l}1.019 \\
(0.01)\end{array}$ & $\begin{array}{l}1.014 \\
(0.01)\end{array}$ & $\begin{array}{l}1.015 \\
(0.01)\end{array}$ & $\begin{array}{l}1.016 \\
(0.01)\end{array}$ \\
\hline IWH & $\begin{array}{c}38.11^{* * *} \\
(3.50)\end{array}$ & $\begin{array}{c}35.28^{* * *} \\
(3.42)\end{array}$ & $\begin{array}{c}22.29^{* * * *} \\
(2.97)\end{array}$ & $\begin{array}{c}36.93^{* * *} \\
(3.48)\end{array}$ & $\begin{array}{c}21.71^{* * * *} \\
(2.95)\end{array}$ & $\begin{array}{c}24.61^{* * * *} \\
(3.04)\end{array}$ & $\begin{array}{c}23.54^{* * * *} \\
(3.00)\end{array}$ & $\begin{array}{c}21.07^{* * * *} \\
(2.94)\end{array}$ \\
\hline Recession & & $\begin{array}{l}1.555 \\
(1.52)\end{array}$ & $\begin{array}{l}1.404 \\
(1.10)\end{array}$ & $\begin{array}{l}1.303 \\
(0.87)\end{array}$ & $\begin{array}{l}1.240 \\
(0.65)\end{array}$ & $\begin{array}{l}1.226 \\
(0.62)\end{array}$ & & $\begin{array}{l}1.268 \\
(0.68)\end{array}$ \\
\hline Inflation rate & & $\begin{array}{l}0.914^{*} \\
(-1.83)\end{array}$ & & & $\begin{array}{l}1.034 \\
(0.59)\end{array}$ & $\begin{array}{c}0.933 \\
(-0.80)\end{array}$ & $\begin{array}{c}0.930 \\
(-0.92)\end{array}$ & $\begin{array}{c}0.896 \\
(-1.07)\end{array}$ \\
\hline $\begin{array}{l}\text { Unemployment } \\
\text { rate }\end{array}$ & & & $\begin{array}{c}1.239^{* * *} \\
(5.59)\end{array}$ & & $\begin{array}{c}1.244^{* * * *} \\
(5.62)\end{array}$ & $\begin{array}{l}1.221^{*} \\
(1.84)\end{array}$ & $\begin{array}{l}1.228^{* * *} \\
(2.04)\end{array}$ & $\begin{array}{l}1.089 \\
(1.17)\end{array}$ \\
\hline $\begin{array}{l}\text { Government } \\
\text { ideology } \\
\text { (rightwing) }\end{array}$ & & & & $\begin{array}{c}0.690 \\
(-1.27)\end{array}$ & $\begin{array}{c}0.716 \\
(-1.30)\end{array}$ & $\begin{array}{c}0.924 \\
(-0.22)\end{array}$ & $\begin{array}{l}1.085 \\
(0.24)\end{array}$ & $\begin{array}{c}0.758 \\
(-1.07)\end{array}$ \\
\hline $\begin{array}{l}\text { GDP growth } \\
\text { rate }\end{array}$ & & & & & & & $\begin{array}{c}0.850^{* * *} \\
(-3.05)\end{array}$ & \\
\hline $1950 \mathrm{~s}$ & & & & & & $\begin{array}{l}0.000^{* * * *} \\
(-22.14)\end{array}$ & $\begin{array}{l}0.000^{* * * *} \\
(-18.19)\end{array}$ & \\
\hline $1960 s$ & & & & & & $\begin{array}{c}0.854 \\
(-0.11)\end{array}$ & $\begin{array}{l}1.314 \\
(0.19)\end{array}$ & \\
\hline $1970 s$ & & & & & & $\begin{array}{l}1.790 \\
(0.63)\end{array}$ & $\begin{array}{l}2.539 \\
(1.00)\end{array}$ & \\
\hline $1980 \mathrm{~s}$ & & & & & & $\begin{array}{l}3.791^{*} \\
(1.89)\end{array}$ & $\begin{array}{l}3.989^{* * *} \\
(1.98)\end{array}$ & \\
\hline $1990 \mathrm{~s}$ & & & & & & $\begin{array}{l}1.042 \\
(0.05)\end{array}$ & $\begin{array}{l}1.029 \\
(0.04)\end{array}$ & \\
\hline $2000 \mathrm{~s}$ & & & & & & $\begin{array}{l}1.750 \\
(0.63)\end{array}$ & $\begin{array}{l}1.786 \\
(0.68)\end{array}$ & \\
\hline $\begin{array}{l}\text { Linear time } \\
\text { trend } \\
\text { Quadratic time } \\
\text { trend }\end{array}$ & & & & & & & & $\begin{array}{c}1.103^{* * *} \\
(4.30) \\
0.999^{* * *} \\
(-3.75)\end{array}$ \\
\hline Observations & 653 & 653 & 653 & 653 & 653 & 653 & 653 & 653 \\
\hline Pseudo R2 & 0.292 & 0.299 & 0.359 & 0.298 & 0.363 & 0.427 & 0.436 & 0.395 \\
\hline
\end{tabular}


Table 5: Regression results, separate regressions by institute. Incidence rate ratios. Poisson model with robust standard errors (Huber/White/sandwich standard errors). Dependent variable: Number of minority votes per institute and report

\begin{tabular}{lccccc}
\hline & DIW & ifo & IfW & IWH & RWI \\
\hline Inflation rate & $0.823^{* *}$ & 0.883 & 1.259 & 1.286 & $0.752^{* * *}$ \\
& $(-2.37)$ & $(-0.60)$ & $(1.33)$ & $(0.86)$ & $(-2.58)$ \\
Unemployment rate & 1.019 & 0.848 & 1.185 & $1.906^{* *}$ & 1.011 \\
& $(0.25)$ & $(-1.29)$ & $(0.94)$ & $(1.98)$ & $(0.09)$ \\
Government ideology & 0.744 & 0.952 & $0.331^{*}$ & 0.423 & $0.110^{* * *}$ \\
(rightwing) & $(-0.94)$ & $(-0.08)$ & $(-1.77)$ & $(-0.97)$ & $(-2.78)$ \\
& & & & & \\
Recession & 0.863 & 0.688 & 0.667 & 1.601 & 0.713 \\
& $(-0.39)$ & $(-0.35)$ & $(-0.48)$ & $(0.90)$ & $(-0.58)$ \\
Linear time trend & $1.081^{* * *}$ & 1.072 & 1.072 & 2.160 & $1.109^{* * *}$ \\
& $(3.31)$ & $(1.21)$ & $(1.19)$ & $(1.02)$ & $(2.71)$ \\
Quadratic time trend & $1.000^{* *}$ & 1.000 & 0.999 & 0.996 & $0.999^{* * *}$ \\
& $(-2.38)$ & $(-0.72)$ & $(-1.05)$ & $(-1.07)$ & $(-2.58)$ \\
Procurement by tender & 0.898 & 0.985 & $0.000^{* * *}$ & $34.64^{* * *}$ & $0.000^{* * *}$ \\
& $(-0.08)$ & $(-0.01)$ & $(-5.63)$ & $(3.44)$ & $(-7.75)$ \\
\hline Observations & 117 & 129 & 126 & 44 & 129 \\
Pseudo R2 & 0.131 & 0.0366 & 0.156 & 0.206 & 0.235 \\
\hline
\end{tabular}

$z$ statistics in parentheses

${ }^{*} p<0.10,{ }^{* *} p<0.05,{ }^{* * *} p<0.01$ 